\title{
Pandemie: zdroj konfliktů a kooperace ve světě
}

\author{
Marek Hrubec \\ Filosofický ústav Akademie věd ČR, CZ
}

HRUBEC, M.: The Pandemic: Disputes and Cooperation in the World Philosophica Critica, vol. 6, 2020, no. 1, ISSN 1339-8970, pp. 88-102

\begin{abstract}
An article deals with social and political aspects of the pandemic. Particularly, it focuses on six dimensions of the COVID-19 (coronavirus) pandemic in various macro-regions of the world. First, it identifies global risks and their consequences. Second, it addresses social issues of solidarity, fear and injustice in struggles for survival and social recognition in intersubjective relations. Third, it maps a quick process of establishment of boundaries, breaking international and transnational interactions and also fragmenting countries into smaller units according to the outbreak. Fourth, it analyses the main different approaches of public institutions to the pandemic in different parts of the world. Fifth, it articulates scenarios of possible future development. Sixth, it formulates a new reconfiguration of global forces, including possible economic, political and other conflicts. In the end, the article touches a problem of racism and xenophobia in the pandemic times, and sees positive possibilities of mutual understanding and cooperation.
\end{abstract}

Key words: Pandemic - Coronavirus - Local - Global - Macroregions - Modernity - Conflicts - Cooperation - COVID-19

Současná pandemie může mít vážné dopady jak na zdraví a životy mnoha lidí, tak na dlouhodobé uspořádání světa. Podobně působily v dějinách jiné závažné nemoci či války. Toto stanovisko zaujímají nejen autoři kritičtí k současnému globálnímu řádu, ale také bývalý ministr zahraničí USA a národní bezpečnostní poradce Henry Kissinger ve svém článku „Koronavirová pandemie navždy změní světový řád“ (Kissinger 2020), kde zdůrazňuje, že je nutné zvládnout současnou pandemii a připravovat se na novou éru. Vláda by měla zajistit ochranu zdraví lidí a chod země a zároveň by všichni měli začít pracovat na proměně podmínek, které by byly schopny reagovat na bezprecedentní společenské, technologické 
a geopolitické proměny. Víme však již, jaký bude rozsah změn? Jürgen Habermas ve svém rozhovoru o koronaviru "Ještě nikdy jsme toho nevěděli tolik o naší nevědomosti“ (Habermas, Schwering 2020) klade důraz na rizikový charakter naší proměňující se komplexní znalostní společnosti. Nejistota se podle něj netýká pouze vědomostí o epidemických rizicích, ale také poznání obtížně předvídatelných důsledků v oblasti společnosti, ekonomiky a politiky.

Tento článek se zabývá závažnými sociálními a politickými aspekty pandemie (koronavirus, COVID-19) v různých makroregionech světa. Nejprve identifikuje globální rizika a jejich důsledky. Za druhé se zabývá sociálními otázkami solidarity, strachu a nespravedlnosti v boji za přežití a společenské uznání v intersubjektivních vztazích. Za třetí mapuje rychlý proces ustavování hranic, omezení mezinárodních a nadnárodních interakcí a také fragmentaci zemí na menší jednotky podle vypuknutí nákazy. Za čtvrté analyzuje hlavní rozdílné přístupy veřejných institucí k pandemii $\mathrm{v}$ různých částech světa. Za páté vysvětluje scénáře možného budoucího vývoje. Za šesté formuluje novou významnou rekonfiguraci globálních sil včetně možných ekonomických, politických a jiných konfliktů. Esej se nakonec dotýká problému rasismu a xenofobie v pandemické době a nahlíží pozitivní možnosti vzájemného porozumění a kooperace.

\section{Globální rizika a jejich důsledky}

Odkazy na rizika současné společnosti navazují na teorii světové rizikové společnosti Ulricha Becka (Beck 1999; Beck 2016), jenž vysvětluje rizikovost prostřednictvím velmi komplexní a technologické provázanosti různých částí společnosti ve světě. Současná pandemie přináší rizika také v oblasti násilí, nebot' je rovněž názornou případovou studií šíření patogenu v potenciální budoucí biologické válce. Vedle možných standardních, jaderných, chemických či kybernetických konfliktů patří biologická válka ke globálním hrozbám současnosti (Hrubec 2019). Obecně platí, že čím rychleji je společnost globalizována, tím více se naráží na rozpory a konflikty, nebot' lidé a společnosti na tento překotný vývoj nejsou ještě připraveny. Lidé přitom tyto rozpory zažívají i ve svém každodenním životě, který na první pohled vypadá běžně a lokálně. Východiskem by mohl být přístup, kterému Stephen Chan ř́ká lokální kosmopolitismus, jenž na jedné straně vychází z místních (afrických, čínských, evropských a dalších) způsobů řešení globálních výzev a na straně druhé má na paměti potřebu společného celoplanetárního jednání (Chan 2018).

Lidstvo má s epidemiemi zkušenost již po tisíce let. Proč má tedy koronavirus tak nečekané zásadní důsledky na životy lidí a celých společností? 
Přestože je nebezpečným akutním dechovým syndromem, lidé ho však mohou kvůli mírnému průběhu podcenit, nebot' někteří mohou zaregistrovat jen běžnou horečku, suchý kašel, únavu a další běžné chřipkové příznaky. Nový koronavirus (SARS-CoV-2) a jím vyvolané infekční onemocnění COVID-19 představuje globální riziko s lokálními dopady, jež by se skutečně nemělo podceňovat, podobně jako v dlouhodobé perspektivě nepodceňujeme nemoci, na něž každý rok zemře nejvíce osob, tj. na kardiovaskulární nemoci, cévní mozkovou př́íhodu, nádorová onemocnění, různé závažné respirační problémy a další onemocnění, která jsou zároveň komorbiditami s COVID-19 (World Health Organization 2018). Kromě toho podle Světové zdravotnické organizace zemře na světě každý rok na sezónní chřipku od 290 tisíc do 650 tisíc lidí, kdy se nakazí stovky miliónů lidí (World Health Organization 2017). Bez zavedení přísných vládních opatření proti koronaviru včetně omezení vycházení a nošení roušek by však v případě koronaviru mohl být oproti obvyklé chřipce počet obětí až několikanásobně vyšší. Nyní na počátku května 2020 je na celém světě evidovaných 3,7 milionu nakažených osob a pres čtvrt milionu úmrtí na koronavirus (Worldometers 2020). Uváděná čísla je však třeba brát hlavně jako možnost sledovat vývojové trendy, nebot' metodologie se $\mathrm{v}$ různých zemích částečně liší a navíc existuje mnoho infikovaných osob bez příznaků. Nové způsoby výpočtů se teprve zavádějí.

\section{Solidarita, strach a nespravedlnost}

Pozitivním jevem koronavirové doby je jistě to, co lze vnímat jako vzedmutí vlny solidarity, kdy lidé doma šijí roušky a rozdávají je potřebným, nosí obědy záchranářům v první linii a pracovníkům na hranicích, v karanténě jim na balkonech a z oken děkovně vždy v domluvenou hodinu tleskají apod. Je však třeba si uvědomit, že jedním z motivů, které stojí v pozadí této charitativní vlny, je strach. Strach v boji o vlastní přežití a o své zdraví, o osud svých blízkých; i nejistota, co vlastně bude dál. Je to existenciální a pro některé rovněž existenční otřes. Není ale vůbec samozřejmé, že bude i nadále nasměřován pozitivním směrem $\mathrm{k}$ větší solidaritě mezi lidmi. Pandemie na jedné straně zvyšuje citlivost lidí vůči nakaženým, zároveň však kvůli strachu lidí o sebe sama zvyšuje také sobectví a nespravedlnost. Je to ambivalentní proces s protichůdnými reakcemi u různých sociálních skupin, bohužel celkově často s negativním výsledkem. Šokující bylo rychlé a téměř neproblematizované rozhodnutí neléčit pacienty nad 75 let ve Španělsku, Itálii či Francii. Je pochopitelné, že velké selhání tamních států ve věci připravenosti na pandemii vedlo lékaře a další zdravotní personál k obtížnému rozhodování jako za klasické války, kdy se péče 
a př́ístroje nedostávají pro všechny, ale je třeba zpochybnit chaoticky přijaté plošné kritérium dělení pacientů, když existuje více spravedlivějších možností. Je smutné vidět, jak rychle odpadají civilizační návyky a kultivace. Podobně asi někteří lidé ve třicátých a čtyřicátých letech rychle přijímali skutečnost, že různé skupiny osob (například př́slušníci židovské menšiny nebo zastánci některých politických názorů) byly obětovány, aby provoz mohl jet téměř nerušeně dál.

Ačkoli se o koronaviru zjednodušeně říká, že je rovnostářský či demokratický, skutečnost je taková, že se sice každý člověk může nakazit, ale především chudší lidé a lidé z marginalizovaných etnických skupin mají horší životní a pracovní podmínky, v nichž je pravděpodobnost jejich nakažení daleko větší než u lidí z vyšších př́ijmových skupin (Norfolk 2020). Přečkání pandemie ve vile s bazénem na ostrově v Karibiku je jistě méně nebezpečné než každodenní dojíždění do práce hromadnou dopravou a pak práce $\mathrm{s}$ mnoha ostatními například v open space kanceláři nebo $\mathrm{v}$ továrně. Značně horší situace je v rozvojových zemích, kde má mnoho lidí nedostatečné nebo žádné zdroje pitné vody či finance na mýdlo, o životě ve favelách a slumech v Latinské Americe, Asii, Africe ale i jinde ani nemluvě. Ženy jsou v rozvojových zemích potenciálně ohroženy na zdraví a životě více, nebot' představují přibližně $70 \%$ globálních chudých. Celosvětově ženy tvoří také přibližně $70 \%$ lidí pracujících ve zdravotnictví, čímž se dostávají do první linie nebezpečí nakažení nemocemi. Podle OSN žije na světě 836 miliónů lidí v chudobě (United Nations Global Compact 2020), zatímco podle jiných výpočtů je tento počet ještě značně větší. Přibližně $40 \%$ globálních chudých přitom žije $v$ Africe a dalších 40 \% v Indii. Zatímco v Africe je však náprava fragmentována do více než padesáti málo rozvinutých zemí (Kasanda 2018), v Indii se centrální vládě ve spolupráci s vládami jednotlivých indických států nabízejí zatím nevyužité možnosti silnější koordinace v indické verzi modernity (Kaviraj 2016), případně s částečnou kooperativní inspirací z Číny (Denisov et al. 2020), která za posledních čtyřicet let vyzvedla z chudoby 800 miliónů lidí. Nepočítáme-li však tento čínský přínos, počet chudých ve světě dlouhodobě roste. Jelikož je ale chudoba trvalý problém, média i politici ve většině částí světa tuto lidskou tragédii už téměř přehlížejí a věnují se jiným, nově vzniklým tématům.

Koronavirus reprodukuje současné nerovnosti a ještě je často zhoršuje. Světový potravinový program uvádí, že kvůli pandemii může být v následujícím roce ohroženo hladem více než čtvrt miliardy lidí (World Food Program 2020). Oxfam odhaduje, že se kvůli koronavirové pandemii může dostat do chudoby o půl miliardy lidí více než dosud, pokud se nepřijmou opatření na pomoc rozvojovým zemím (Oxfam 2020). To je důvodem, proč 
se lidé v rozvojových zemích nyní obávají rozšiření koronaviru. Nancy Fraserová v této situaci zdůrazňuje nutnost krátkodobých i strategických aktivit, analýz a alternativních modelů, nebot' se již nelze vracet do začarovaného kruhu chudoby a škrtů (Fraser 2020). Eduardo Suplicy či Josué Pereira da Silva prosazují v této situaci jako řešení pro Brazílii všeobecný základní př́ijem, jehož reálné zavedení má nyní stále větší podporu nejen v ekonomicky a politicky oslabené Brazílii (Mena 2020; Pereira da Silva 2014), ale také ve Španělsku a dalších zemích.

\section{Vytváření hranic}

Pandemie se sice globálně šírí, ale zároveň vytváří prostorovou fragmentaci a uzavřenost. Často můžeme v médiích číst, že místo společných globálních př́istupů v OSN, ve Světové zdravotnické organizaci či v rámci Evropské unie dochází k štěpení a uzavírání hranic národních států. Národní státy přinejmenším v Evropské unii a dalších západních zemích zavedly nouzové stavy a přijaly nezbytná opatření, což však ještě neznamená, že dlouhodobě posílily svoji moc v ekonomických a dalších záležitostech. Korporace nechaly státní správu v nouzovém stavu spravovat krizovou situaci, kdy byli na životech a zdraví masově ohroženi jejich producenti a konzumenti zboží. Pokud však vlivné velké firmy začaly považovat restriktivní opatření za př́liš dlouhá a ztrácet zisk, lobbovaly s požadavkem na uvolnění vládních opatření a vláda následně vše poslušně urychlila.

Např́íklad v USA nejprve důležitá restriktivní opatření nebyla ani zavedena, nebot' nerušený chod firem tam byl kvưli zisku považován za cennější než lidské životy a zdraví. Řada tamních občanů a politiků však tento malthusiánsky inspirovaný př́istup nesdílí, nebot’ mají blíže k sociálnější koncepci, jakou se k těmto otázkám přistupuje ve většině zemí kontinentální Evropy, a vynucují si alespoň základní opatření. Nejen stát New York, ale např́klad také Kalifornie, která je sama pátou největší ekonomikou světa, zaujala serióznější a restriktivnější opatření proti koronaviru než federální vláda.

Zde je vidět, že štěpení má značně větší sílu než jen omezování mezinárodních a transnacionálních aktivit do hranic národních států. Například uzavření nejen mezinárodní, ale i místní dopravy se kvůli koronaviru odehrálo na řadě míst světa. Hranice se dočasně přepisují tím, že dochází ke štěpení uvnitř zemí. Obrazně řečeno tedy nejde jen o návrat k národním státům, ale dokonce také k městským státům. $V$ př́ípadě potřeby se izolují kraje, okresy, města či vesnice, aby se ze silně nakažených oblastí 
virus nešiŕril dále. V České republice šlo například o Litovelsko, v Číně je tím všeobecně známý Wu-chan.

Virus se pochopitelně nejvíce šíří v místech s velkou koncentrací lidí. Jedenáctimilionový Wu-chan, osmimilionový New York, čtrnáctimilionové Dillí, devítimilionový Londýn i čtyř a půl milionové Nairobi jsou klasickými př́pady. Takovéto metropole uvnitř zemí jsou populačně a ekonomicky větší než mnohé národní státy. Odtud mnohé z nich také čerpají svoje možnosti reagovat na pandemii. $\mathrm{V}$ důsledku neoliberálního omezování role veřejných institucí včetně role státu či měst však v řadě západních i dalších zemí v posledních desetiletích došlo navzdory částečnému využití veřejných institucí po globální finanční a ekonomické krizi 2008 pouze $\mathrm{k}$ částečné připravenosti na pandemii. Přitom zkušenosti z minulých epidemií a pandemií ve světě jsou už značné.

Specifická opatření jsou zapotřebí na mnoha místech v rozvojových zemích, kde jsou chudí lidé závislí na každodenním obstarávání obživy. Místní trhy jsou pro ně často zásadním místem pro získávání věcí nezbytných pro přežití. Jejich omezení by proto měla sledovat případné zajištění potravin a dalších nezbytností místní či národními vládami, agenturami OSN a humanitárními organizacemi.

\section{Odlišné př́stupy k pandemii}

Vlády $\mathrm{v}$ různých makroregionech světa zvolily odlišné přístupy k jeho šíření. Nicméně základních přístupů existuje pouze několik a mezi nimi škála možností. Jedním z nich jsou přísná opatření s uzavřením nakažených oblastí, omezení vycházení, nošení roušek, zavření výroby, obchodů apod. Tento přístup zavedla Čína. Česká republika a Slovensko dostaly čas na rozmyšlenou, než virus přišel do Evropy. Nejprve vyčkaly na vhodnou dobu, aby reakce nepřišla překotně př́liš brzy nebo př́liš pozdě, a již jako jedny z prvních $\mathrm{v}$ Evropě zareagovaly přísnými opatřeními. Výsledkem je, že - možná rovněž díky systematickému očkování na jiné choroby ve střední a východní Evropě - je počet infikovaných a úmrtí v porovnání se západoevropskými zeměmi relativně malý. Řada zemí kontinentální Evropy reagovala svými vládními opatřeními následně podobně jako Česká republika a Slovensko. Pozoruhodné je ve srovnání Německo, jenž má sice jako poměrně velká země hodně nakažených (na 6. místě na světě), ale v porovnání s jinými zeměmi s podobným počtem nakažených má patrně díky rozvinutému organizovanému zdravotnictví a dalším opatřením sociálního státu třikrát až čtyřikrát menší počet úmrtí.

Za druhé, jiné země či jejich části především v jihozápadní Evropě, konkrétně severní regiony Itálie a Španělsko, na začátku pandemie zareagovaly 
laxně se zpožděním a dnes jsou zeměmi s největším počtem nakažených v Evropě (celkově na 2. a 3. místě na světě). Pak sice byla přijata podobně přísná opatření jako v Číně (na 11. místě na světě), ale ta už nemohla mít ten pozitivní efekt jako např́iklad v České republice, přestože byla v Itálii později zavedena i přísněji. Také Francie, Rusko a Brazílie nejprve neodhadly situaci a nyní patří navzdory přijatým opatřením k zemím s nejvíce nakaženými (na 5., 7. a 9. místě na světě). Podobně na začátku podcenili virus v Turecku a Íránu, kde je dnes i přes restrikce nejvíce nakažených v muslimských zemích (celkově na 8. a 10. místě na světě). V arabských zemích ale mají se svojí islámskou verzí modernity promýšlením tradice lepší výsledky (Al-Džábirí 2018). Obdobné se tomu zdá být v subsaharské Africe, ale tam situace zatím vypadá relativně velmi příznivě spíše kvůli malému počtu testování a malé evidenci problému, přičemž hrozí masivní šíření.

Za třetí, odlišný postoj zaujaly v angloamerickém světě se svým přístupem laissez faire, jak jsem již naznačil. Po ohlášení původního odhadu dvou set tisíc úmrtí divokým promořováním kvůli získání „stádní imunity“ musela britská vláda pod tlakem veřejnosti svůj přístup částečně přehodnotit a zpř́ísnit pravidla, ale přes tato přijatá opatření odhad stále činí téměř čtyřicet tisíc očekávaných úmrtí (Boseley 2020). To je téměř nejvíce ze všech zemí světa, hned po prognózovaných údajích v USA. Oligopolně definovaný trh v USA a Británii situaci nevyřešil. Již ted' je situace v USA globálně nesrovnatelně nejhorší, tj. nejvíce nakažených na světě (1 237 633) a nejvíce úmrtí na světě (72 271); Británie patří mezi čtyři země na světě s nejvíce nakaženými a je po USA druhou zemí s nejvyšším počtem úmrtí (více než 29 tisíc) (Worldometers 2020). Neoliberální režim má své fatální důsledky.

Existuje rovněž možnost dalšího kroku, který volí např́íklad Česká republika, jímž je zavádění chytré karantény a dalších technologických pomůcek pro trasování apod. Trasování kontaktů infikovaných osob umožňuje mimo jiné užití adekvátnějšího jazyka, nebot' přitom mluvíme o tom, kdo se stal prostředníkem přenosu viru na někoho dalšího. Jinak se totiž často hovoří o tom, „že se virus šíríi, čímž se mu připisují značně přehnané schopnosti. Virus se sice může pomalu omezeně teritoriálně šírit i sám, ale hlavní dynamiku přenosu mu dáváme my lidé tím, že ho sami na sobě a v sobě šíríme auty, letadly, loděmi a dalšími prostředky i transkontinentálně nad rámec jeho schopností. Proto je nyní důležité neukvapit se při uvolňování vládních opatření.

Nové technologické př́ístupy se již osvědčily v konfuciánsky ovlivněném světě ve východní Asii, konkrétně v Jižní Koreji či v městském státě Singapuru. V současné době je v boji proti pandemii přijímá jako dočasné 
řešení stále více politiků a občanů. Nejde přitom jen o boj o přežití, ale také o boj o jejich uznání jako lidských bytostí, jež chtějí být respektováni jako ti, kteří chrání své blízké a další osoby ve svém okolí. Občas se připomíná, že dosud byly tyto digitální technologické př́istupy v Evropě často považovány za pŕiliš velký zásah do soukromí a za elektronickou formu sociální kontroly. Na rozdíl od východoasijských společností, kde je průnik digitalizace do životů lidí větší - jako by se ovšem zapomínalo na ochotu občanů evropských zemí poskytovat běžně svá data zábavním sociálním sítím. Tato rizika je třeba mapovat a obrátit je pozitivně ve větší elektronickou demokratickou participaci občanů.

Přijetí chytré karantény a dalších forem trasování však nutně nemusí znamenat celkovou změnu ochrany soukromí. Je možné přijmout striktnější přístup kontroly a poté její použití jen $\mathrm{v}$ případě nakažení $\mathrm{v}$ době pandemické krize. $V$ běžném období poté může platit volnější přístup. Nicméně je třeba vidět opatření v širších souvislostech v rámci toho, že lidé jsou v boji o přežití a zdraví ochotni podstoupit různá plošná opatření včetně plošné karantény, nošení roušek, uzavření výroby a obchodů apod. Užití nových technologií tedy není izolovaný jev. Zdá se být zřejmé, že vstupujeme do další etapy nové éry, kterou umožnila právě pandemie. Jinak by opatrnost lidí při přijímání technologických opatření byla zřejmě značně větší. $V$ budoucnu mohou být podobné formy technologického sledování uplatněny také v rámci globálního vládnutí, aby se zamezilo globální pandemii nebo se čelilo jiným rizikům. Do jisté míry už přinejmenším od opatření přijatých po 11. září 2001 žijeme v této éře sociální kontroly (evidence emailů, telefonů, a tím i našeho pohybu v USA, EU ad.). V době krizí či bojů, kdy jde o přežití, se přístupy válečného kapitalismu a válečného socialismu v lecčem shodují.

Podobné přístupy budou pravděpodobně vyžadovány také v souvislosti s klimatickými změnami v případě budoucích př́rodních katastrof, jakými jsou např́klad záplavy (Suša - Stáahel 2016; Suša 2019). Pandemie jen učinila další krok tímto směrem. Stále větší zásahy člověka do divoké př́rody - například kácení amazonského pralesa, masivní industrializované druhy zemědělství - souvisí i s širrením různých virů do lidské populace a se vznikem epidemií. Člověk v divoké přírodě naráží na druhy virů, jež dříve zůstávaly od života člověka odděleny (Shan 2020a; 2020b). Rovněž tání permafrostu v sobě skrývá historické patogeny, které na nás ještě $\mathrm{v}$ dalších epidemiích čekají.

Postupné proměny životního prostředí vlivem lidského zásahu sice silně zesílily prostřednictvím vzniku a rozvoje průmyslové společnosti v moderní době, ale jedná se o daleko dlouhodobější problém v řádech tisíců let, který započal již etablováním lidské civilizace (Hrubec 2019), 
především pak západního civilizačního okruhu. Nicméně dlouhodobé přírodní cykly (střídání dob ledových a meziledových i menší cykly) a nepravidelné události na planetě zde hrají rovněž svoji roli.

\section{Scénáře dalšího vývoje}

Přestože se v médiích zdá, že nic není trvalejšího než aktualita, je třeba získat časový nadhled. Ve volné návaznosti na knihu Philipa Tetlocka Superprognózy o náročných předpovědních projektech se objevilo několik komplexních scénářu předpokládaného vývoje schopnosti zvládnout organizační reakci na nákazu. Pro naše účely zde postačí odkázat na tři základní scénáře, které pro následující období vypracoval mezinárodní tým ACAPS (ACAPS 2020). Lze naznačit, že první scénář předpokládá zvládnutí koronavirové pandemie ve vysokopř́ijmových zemích opatřeními tak, aby bylo možné zajistit základní zdravotnické služby tím, že se identifikují a zajistí nové př́pady. Jejich ekonomické a sociální systémy se revitalizují, stejně jako cestování. Ve středně a nízkopříjmových zemích se rovněž podaří zcela nezatížit zdravotní systém díky menšímu počtu případů. Výsledkem by bylo zvládnuté zadržení velkého šíření chudoby. Druhý scénář počítá sice s nárůstem počtu případů ve vysokopříjmových zemích v řádu týdnů, ale s jejich stabilizací v řádu měsíců. Cestování v rámci kontinentů se zde uvolňuje především v oblasti ekonomického rozjezdu. Pouze některé středně a nízkoprríjmové země by v takovém případě byly schopny zadržet velký nárůst počtu případů. Třetí scénář předpokládá nejhorší průběh s vysokou globální mortalitou a nedostatečným zajištěním základních zdravotnických a dalších služeb. Kontrola nad pandemií by si vyžádala vysoké náklady včetně finančních a tomu odpovídající ekonomický propad jak ve vysokopř́ijmových, tak v nízko a středněpříjmových zemích. Není však zatím možné dobře predikovat, zda a kdy nastanou druhá či třetí vlna, které by samozřejmě mohly přinést kombinaci uvedených scénářů a další prvky.

Krátkodobé důsledky pandemie přitom sice znamenají výrazný pokles ekonomických aktivit, ale z dlouhodobého hlediska nemusejí být drastické. Na rozdíl od světové finanční a ekonomické krize 2008 se nejedná o ekonomickou příčinu poklesu výkonnosti, takže po odeznění neekonomické (virové) př́činy se ekonomika může do velké míry vrátit do původního stavu. Bezprecedentní pozastavení a opětný rozjezd současného objemu ekonomiky však bude mít i své sociální důsledky. Mnoho lidí ztratí práci a pak se již nebudou chtít vrátit do té původní, nevyhovující. Pravděpodobně nastane masivní přesun pracovních sil, kterým se umožní také vznik nových míst, někdy lepších, jindy však i horších. Tím se však 
nevyřeší dosavadní strukturální ekonomické a finanční problémy globálního kapitalismu, což bude znamenat zásadní problém v budoucí krizi.

Důležitým faktorem pandemie je skutečnost, že se šírí po planetě postupně, a negativní ekonomické dopady jsou tedy časově rozfázovány. Globální konsekvence jsou tím částečně zmírněny. Zatímco virová vlna se v Číně už dostává ke svému závěru, pokud nenastane další etapa šíření, Evropa by mohla být brzy na svém vrcholu. Po svém propadu v prvním čtvrtletí se čínská ekonomika nyní začíná opět zvedat. Tento rok bude slabší, ale příští rok už zase může nabrat sílu. Bude ale záležet nikoliv pouze na čínských podnicích, institucích a spotřebitelích, ale také významně na tom, jak se bude ekonomika kvůli viru vyvíjet především v Evropě a USA. Například v Německu se odhaduje pokles ekonomiky o 5 až $20 \%$. Jelikož je Německo ekonomickým lídrem v Evropě, je na něj navázána ekonomika také řady dalších menších okolních zemí, což může mít na evropskou a potažmo globální ekonomiku značný vliv. Některé prognózy předpokládají propad světové ekonomiky v tomto roce až o $30 \%$. Každopádně východoasijské země mohou být díky časovému posunu virové vlny v globální výhodě, protože dřive než západní země obnovují své ekonomické aktivity.

V některých částech světa se však není třeba obávat omezení objemu ekonomiky. Západní země, některé země a oblasti východní Asie či Perského zálivu žijí neodůvodněným konzumismem, který je závislý na globálních nespravedlnostech a ničení životního prostředí. Omezení těchto ekonomických aktivit o desítky procent by patrně bylo ku prospěchu. Nicméně při omezování objemu ekonomiky je nutné brát zřetel na opačné potřeby většiny lidí v rozvojových zemích, kde je naopak potřebný růst ekonomiky nutný pro eliminaci chudoby a zvyšování životní úrovně. Stručně řečeno, pointou by byl de-growth v rozvinutých zemích a growth v rozvojových. Nicméně hlavní kritéria posuzování by neměla být v oblasti ekonomického (ne)růstu, ale v oblasti zvyšování životní úrovně.

$\mathrm{V}$ různých oblastech světa se $\mathrm{k}$ pandemii přistupuje různými způsoby nejen na vládní rovině, ale také na rovině různých skupin osob, přičemž existují pozitivní př́klady kooperace - včetně interkulturního dialogu. Řada dobrovolníků různých profesí v současné situaci svojí snahou napomáhá napravit nepřipravenost veřejných institucí. Například lékařští experti z Evropy, USA a Číny uspořádali Mezinárodní sympozium o léčení COVID-19, které zaměřili na prevenci, kontrolu a léčbu nemoci. Na různých sekcích po celém světě se ho online zúčastnilo čtyřicet pět tisíc lidí. Rovněž se konal mimořádný summit politických lídrů na téma COVID-19. Více než sedmdesát výzkumných týmů se nyní snaží vyvinout vakcínu (World Health Organization 2019). Toto hektické období přináší 
mnoho nejrůznějších nápadů, iniciativ i alternativ společenského uspořádání, podobně jako po globální ekonomické krizi 2008 (Hohoš - Dinuš 2011). V budoucnu bude důležité nenechat tento vějír možností padnout a systematicky vybrat to nejdůležitější do celkové př́ípravy na případnou další pandemii či podobné problémy, abychom pak zase všichni nebyli překvapeni.

\section{Přeskupení globálních sil}

Současná politika USA se může na první pohled zdát antiglobalizační a v některých aspektech skutečně je. Při podrobnějším pohledu ale vidíme, že Trumpův přístup je do velké míry jen prostředkem, a nikoli cílem. Trump sám je transnacionální businessman a požaduje, aby se Čína více otevřela USA, například ve finančním sektoru. Dále požaduje, aby Čína více nakupovala americké zboží, například zemědělské produkty. To je přece globalizační, a nikoli antiglobalizační trend. Pochopitelně se to ale netýká strategického průmyslu, primárně technologií využitelných k vojenským účelům, v němž USA chtějí dominovat, a proto omezují Huawei a další čínské firmy. USA vnímají Čínu jako svého rivala a snaží se ji zadržovat a omezovat její globální vliv. To platí rovněž o vztahu k Rusku, i když nikoli primárně z ekonomických, ale z vojenských důvodů. Přístup k Rusku, který zaujímají USA a částečně EU, přiměl Rusko k vytvoření integrovanějšího partnerství s Čínou a dalšími partnery v Eurasii (Lukin 2020). Je přitom však evidentní, že současné vedení USA, Číny i Ruska má (i když každé z rozdílných důvodů) společný zájem, který spočívá v nespokojenosti se současným stavem uspořádání světa a ve snaze o globální přeskupení. $S$ tím je v souladu i většina rozvojových zemí, ovšem zase z jiných důvodů. Globální výroba a obchod tedy budou v budoucnu pokračovat, ale budou plné kontradikcí. $\mathrm{V}$ některých směrech bude více lokalizace, $\mathrm{v}$ jiných ale bude pokračovat makroregionalizace a globalizace.

Již nyní začínají snahy o relokaci menšího počtu zahraničních výrobních kapacit z Číny do Vietnamu či Mexika, přičemž se tento trend může časem zvětšit a mírit také do Evropy a USA - rovněž v návaznosti na americko-čínskou obchodní válku $\mathrm{v}$ posledních letech. To může vést $\mathrm{k}$ částečné revitalizaci výrobních kapacit v místě spotřeby, což může být ze střednědobé a dlouhodobé perspektivy smysluplné pro všechny strany. Čína může tuto částečnou reorientaci nahradit tím, že v jiných smysluplných aktivitách naváže na svoji novou hedvábnou stezku, tedy projekt Iniciativy pásma a cesty započatý roku 2013, kterým vytváří svoji alternativní verzi globálních interakcí (Kreuzzieger - Hrubec 2020). Tím zintenzivňuje svoji spolupráci s globálním Jihem (tedy s Afrikou, Latinskou Amerikou i Asií) 
a rovněž se střední a východní Evropou. Takto by mohlo po čtyřiceti letech od zahájení čínských reforem a následného rozvoje čínského systému dojít k politicko-ekonomické změně globálního rozsahu. Čína zároveň posiluje domácí spotřebu, čímž se stává méně závislá jak na USA a př́ípadně také západních a dalších zemích, tak celkově stále méně na svém exportu. Jedná se o uplatnění další vývojové fáze modernity s čínskými charakteristikami v domácí a zahraniční sféře (Wei 2017).

$\mathrm{V}$ budoucnu se celkově bude jednat o značně globalizovanou společnost, pokud ji porovnáme s tím, jak byla provázána například před dvěma dekádami, natož před dobytím amerického kontinentu. Jde tedy skutečně spíše o korekci než o deglobalizaci. Novinkou je ted' spíše náhlý průběh těchto změn než změny samé. Globální pandemie dobře odhaluje skutečnou povahu dosavadní globalizace. Nikdy to nebyl nějaký bezproblémový proces globální integrace, ale spíše proces plný konfliktů. Globální interakce probíhaly v dějinách vždy rozporuplně ve vlnách globálních integrací, následných dezintegrací a poté ještě větších globálních integrací. Po částečných deglobalizačných trendech bude možné usilovat o globální komunikaci a spolupráci na vhodnější a spravedlivější bázi s větším důrazem na vyváženost jednotlivých rovin - od roviny lokální přes národní a regionální a makroregionální až po globální. Současné překotné proměny však mohou mít různé negativní politické, ekonomické a sociální dopady v podobě recese či krize, což se již začíná projevovat. Konsekvence se už objevují také v rovině vyostřených politických, diplomatických a zpravodajských sporů, jež mohou vést i ke střetům ozbrojeným. Dosavadní realita války s řadou islámských zemí se přitom přesouvá k nebezpečí roznícení sporů rovněž s Î́ránem a na Dálném Východě a zostření sporů na pomezí střední a východní Evropy.

\section{Závěr: proti rasismu a nesnášenlivosti}

Zvláštní reportérka OSN pro problémy rasismu, xenofobie a nesnášenlivosti Tendayi Achiumeová (Kenny 2020) kritizovala „nezodpovědnou, diskriminační státní rétoriku" některých politiků, kteří komentovali pandemii v jednotlivých zemích. Upozornila, že projevy rasismu a nesnášenlivosti jsou nepřijatelné ve státních politikách a výrocích. Proti nim na Mezinárodním dni pro vymýcení rasové diskriminace zdůraznila: „Krize jako je koronavirová pandemie nám připomíná, že jsme všichni propojeni a že naše živobytí je vzájemně provázané." V souladu s tím Tedros Adhanom Ghebreyesus, který vede Světovou zdravotnickou organizaci, požadoval, aby se pandemie přestala politicky zneužívat (UN News 2020). 
Obvykle se setkáváme s tím, že se poukazuje na nezamýšlené důsledky pozitivních událostí. Ulrich Beck však ve své knize Metamorfóza světa (Beck 2016) upozornil, že je důležité vidět také opak, tedy pozitivní důsledky negativních událostí, neboli emancipační charakter katastrof. Také z koronavirové pandemie si můžeme odnést ponaučení a emancipovat se z dosavadních nespravedlivých a nesnášenlivých pout. Bude přitom třeba společně čelit jak zdravotním rizikům, tak sociálním a ekonomickým nerovnostem, politickým konfliktům, technologickým rizikům, environmentální krizi a dalším závažným problémům. Bude ovšem zapotřebí jak respekt k úspěšným lokálním př́istupům k pandemii, tak také ochota vzájemně se od sebe učit a společně koordinovat jednotlivé kroky. V každém makroregionu světa již zaznívají různé inspirativní a inovativní podněty pro budoucí místní i globální uspořádání.

\section{Literatura}

ACAPS (2020): COVID-19. In: Scenarios. 10.4.2020.Web. 30.4.2020.<https://www. acaps.org/special-report/covid-19-scenarios?utm_source=ACAPS\&utm campaign $=\mathrm{a} 3 \mathrm{~d} 959 \mathrm{e} 58 \mathrm{e}-$

EMAIL_CAMPAIGN_2020_04_09_02_44_COPY_01\&utm_medium=email\&utm term=0_8a07424dc9-a3d959e58e-193556217>.

AL-DŽÁBIRÍ, M. A. (2018): Kritika arabského rozumu. Úvod. Praha: Filosofia.

BECK, U. (1999): World Risk Society. Cambridge: Polity.

BECK, U. (2016): The Metamorphosis of the World: How Climate Change is Transforming Our Concept of the World. Cambridge: Polity.

BOSELEY, S. (2020): US institute revises down forecast for UK coronavirus deaths. In: The Guardian 11. 4. 2020. Web. 30. 4. 2020. <https://www. theguardian.com/world/2020/apr/11/us-institute-revises-down-forecastfor-uk-coronavirus-deaths>.

CHAN, S. (2018): The Problematic Non-Western Cosmopolitanism in Africa Today. Human Affairs, 28 (4), 351 - 366.

DENISOV, I. - SAFRANCHUK, I. - BOCHKOV, D. (2020): China-India Relations in Eurasia: Historical Legacy and Changing Global Context. In: Human Affairs, 30 (2), $224-238$.

FRASER, N. (2020): The left reflects on the global pandemic. In: Transform! Europe, 16. 4. 2020. Web. 30. 4. 2020. <https://www.transform-network.net/en/ calendar/event/the-left-reflects-on-the-global-pandemic-nancy-fraser/>.

HABERMAS, J. - SCHWERING, M. (2020): Jürgen Habermas über Corona „So viel Wissen über unser Nichtwissen gab es noch nie“. Frankfurter Rundschau, 10. 4. 2020. Web. 30. 4. 2020. <https://www.fr.de/kultur/gesellschaft/ juergen-habermas-coronavirus-krise-covid19-interview-13642491.html? fbclid=IwAR 1 pksaBDXNP5kyN6NTJlUaC0 kuxgQtIS6 VwbYfvutXUlHCsqojM-p1ymS8>.

HOHOŠ, L. - DINUŠ, P. eds. (2011). Svet v bode obratu. Bratislava: Veda. 
HRUBEC, M. (2019a): Social and environmental conflicts or sustainable development? In: Civitas, 19 (2), 281 - 295.

HRUBEC, M. (2019b): Threat of limited nuclear war. In: Critical Sociology, 45 (6), $785-798$.

KASANDA, A. (2018): Současná africká sociální a politická filosofie. Praha: Filosofia.

KAVIRAJ, S. (2016): Modernita a politika v Indii. In: Kreuzzieger, M. - Lánský, O. (eds.): Modernita/modernity $v$ eurasijských kulturních a civilizačních kontextech. Praha: Filosofia.

KENNY, P. (2020): UN expert hits out at COVID-19 xenophobia. In: $A A$, 23. 3. 2020. Web.30.4.2020.<https://www.aa.com.tr/en/latest-on-coronavirus-outbreak/ un-expert-hits-out-at-covid-19-xenophobia/1776554>.

KISSINGER, H. (2020): The Coronavirus Pandemic Will Forever Alter the World Order. In: Wall Street Journal 3. 4. 2020. Web. 30. 4. 2020. <https://www. wsj.com/articles/the-coronavirus-pandemic-will-forever-alter-the-worldorder-11585953005 ?fbclid=IwAR0A_06 PmvRcRQV 2 umVY4 TNcpY8AYctG3p0SpjGh2ww2Jk1M47KoUAh8ZIs>.

KREUZZIEGER, M. - HRUBEC, M. (2020): Od pandemie k revitalizaci: čínská zkušenost s koronavirem. In: Philosophica Critica, viz níže v tomto tematickém čísle časopisu.

LUKIN, A. (2020): Sino-Russian Cooperation as the Basis for Greater Eurasia. In: Human Affairs, 30 (2), 174 - 188.

MENA, F. (2020): "Tudo indica que vou viver para ver a renda básica implementada", diz Eduardo Suplicy. In: Folha de S. Paolo 13. 4. 2020.

NORFOLK, A. (2020): Black coronavirus patients are dying at double the rate of white in hospitals. In: The Times 24. 4. 2020. Web. 30. 4. 2020. <https://www. thetimes.co.uk/article/black-coronavirus-patients-are-dying-at-double-therate-of-white-in-hospitals-lddtfs6vz>.

OXFAM (2020): Half a billion people could be pushed into poverty by coronavirus, warns Oxfam. 9. 4. 2020. Web. 30. 4. 2020. <https://www.oxfam. org/en/press-releases/half-billion-people-could-be-pushed-povertycoronavirus-warns-oxfam>.

PEREIRA DA SILVA, J. (2014): Por que renda básica? Sao Paolo: Annablume.

SHAN, S. (2020a): Think exotic animals are to blame for the coronavirus? Think again. In: The Nation 18. 2. 2020. Web. 30. 4. 2020. <https://www.thenation. com/article/environment/coronavirus-habitat-loss/>.

SHAN, S. (2020b): Accelerating habitat loss behind Covid-19. The microbes, the animals and us. In: Le mode diplomatique. March 2020. Web. 30. 4. 2020. <https://mondediplo.com/2020/03/05coronavirus>.

SUŠA, O. - SŤAHEL, R. (2016): Environmetální devastace a sociální destrukce. Praha: Filosofia.

SUŠA, O. (2019): Global risks and conflicts: the social, environmental, and political consequences. In: Critical Sociology, 45 (6), 829 - 843.

TETLOCK, P. E. (2016): Superprognózy: Umění a věda předpovídání budoucnosti. Brno: Jan Melvil Publishing. 
UNITED NATIONS GLOBAL COMPACT, Poverty (2020): Web. 30. 4. 2020. <https:// www.unglobalcompact.org/what-is-gc/our-work/social/poverty>.

UN News. No need to politicize COVID-19 (2020): 8. 4. 2020. Web. 30. 4. 2020. <https://news.un.org/en/story/2020/04/1061392>.

WEI, X. (2017): Ekonomická a politická transformace Číny. Praha: Filosofia.

WORLD FOOD PROGRAM (2020): 2020 - Global Report on Food Crises. 20. 4. 2020. Web. 30. 4. 2020. <https://www.wfp.org/publications/2020global-report-food-crises>.

WORLD HEALTH ORGANIZATION (2017): Up to 650000 people die of respiratory diseases linked to seasonal flu each year. 14. 12. 2017. Web. 30. 4. 2020. <https://www.who.int/news-room/detail/14-12-2017-up-to-650-000people-die-of-respiratory-diseases-linked-to-seasonal-flu-each-year>.

WORLD HEALTH ORGANIZATION (2018): The top 10 causes of death. 24. 5. 2018. Web. 30. 4. 2020. <https://www.who.int/news-room/fact-sheets/detail/thetop-10-causes-of-death>.

WORLD HEALTH ORGANIZATION (2019): Global research on coronavirus disease (COVID-19). Web. 30. 4. 2020. <https://www.who.int/emergencies/diseases/ novel-coronavirus-2019/global-research-on-novel-coronavirus-2019-ncov>.

WORLDOMETERS (2020): Web. 5. 5. 2020. <www.worldometers.info/ coronavirus/>.

doc. PhDr. Marek Hrubec, PhD.

Centrum globálních studií

Filosofický ústav Akademie věd ČR

Jilská 1, 11000 Praha 1

Česká republika

hrubec@flu.cas.cz 